\title{
Microbiological Quality, Transmission of Resistant Bacteria, and Genetic Characterization in Fish Sold in Town Fairs in the Recôncavo da Bahia Region, Brazil
}

\author{
Sanmily Santos Damacena, Ludmilla Santana Soares e Barros \\ Center of Environmental and Biological Agrarian Sciences, UFRB, Cruz das Almas, Brazil \\ Email: barros@ufrb.edu.br
}

How to cite this paper: Damacena, S.S. and e Barros, L.S.S. (2019) Microbiological Quality, Transmission of Resistant Bacteria, and Genetic Characterization in Fish Sold in Town Fairs in the Recôncavo da Bahia Region, Brazil. Food and Nutrition Sciences, 10, 1072-1084.

https://doi.org/10.4236/fns.2019.109077

Received: July 31, 2019

Accepted: September 2, 2019

Published: September 5, 2019

Copyright $\odot 2019$ by author(s) and Scientific Research Publishing Inc. This work is licensed under the Creative Commons Attribution International License (CC BY 4.0).

http://creativecommons.org/licenses/by/4.0/

\begin{abstract}
Informal fish marketing is an important source of food and income for many families. However, it is also a public health issue, since the quality of fish can be compromised during marketing. The microbiological quality of fish sold in town fairs in the municipalities of the Bahia Reconcavo region, Brazil, was assessed to characterize isolates based on antimicrobial susceptibility and to investigate gene virulence. Samples of mullets (Mugil sp.), mussels (Mytella sp.), and mollusks (Anomalocardia brasiliana) were collected in town fairs in the municipalities of Cachoeira, Cruz das Almas, and Santo Antônio de Jesus. The presence of mesophylls, molds and yeasts, total coliforms, Escherichia coli, and Staphylococcus aureus was evaluated. E. coli and S. aureus isolates were subjected to antimicrobial susceptibility tests and the presence of the gene stx in E. coli isolates was investigated. Total coliforms and $S$. aureus ranged between 0 and $9.50 \log \mathrm{CFU} / \mathrm{g}$, while high counts of mesophylls, molds, and yeasts were detected. E. coli had greater resistance $(76.8 \%)$ to amoxicillin and $S$. aureus had greater sensitivity to gentamicin. The st $x$ gene was not identified in any of the samples studied. Results showed that some fish sold in the town fairs of the three municipalities possessed unsatisfactory microbiological quality, which may pose risks to consumer health, and may be vectors for the dissemination of bacteria resistant to different antimicrobial agents.
\end{abstract}

\section{Keywords}

Mugil brasiliensis, Mytella spp., Anomalocardia brasiliana, Resistance, Virulence 


\section{Introduction}

Fishing is an economic activity that promotes social benefits worldwide, and fish is an important food source. Fish is rich in protein and contains all the basic amino acids needed for growth and maintenance in humans [1]. However, fish intake may be a health risk for consumers since, after capture, fish quality deteriorates gradually with high bacterial proliferation. Fish intake is frequently associated with food borne illnesses (FBIs) [2], a serious public health issue. In fact, millions of people are infected with FBIs every year. Fish can transmit pathogenic microorganisms to people, mostly due to environmental contamination [3].

Fish is mainly sold in town fairs, which is a source of great concern because this sort of market can have serious issues related to hygiene and sanitary conditions [4]. Another issue is growing antimicrobial resistance, which involves an increasing number of bacterial species and new resistance mechanisms [5]. The presence of resistant bacteria in food of animal origin may cause the exchange of genetic factors that codify antimicrobial resistance, triggering the dissemination of resistance genes among bacteria [6].

This study evaluates the microbiological quality of fish sold in town fairs in the municipalities of Cachoeira, Cruz das Almas, and Santo Antônio de Jesus, Brazil, tests the sensitivity of Escherichia coli and Staphylococcus aureus to commercial antimicrobial factors, and investigates the presence of the gene stx in E. coli isolates.

\section{Materials and Methods}

Sample collection was undertaken in weekend town fairs in Cachoeira, Cruz das Almas, and Santo Antônio de Jesus, Brazil between April and June 2018 (Figure 1). Samples were obtained by buying fish wrapped in the same manner as when consumers buy it.

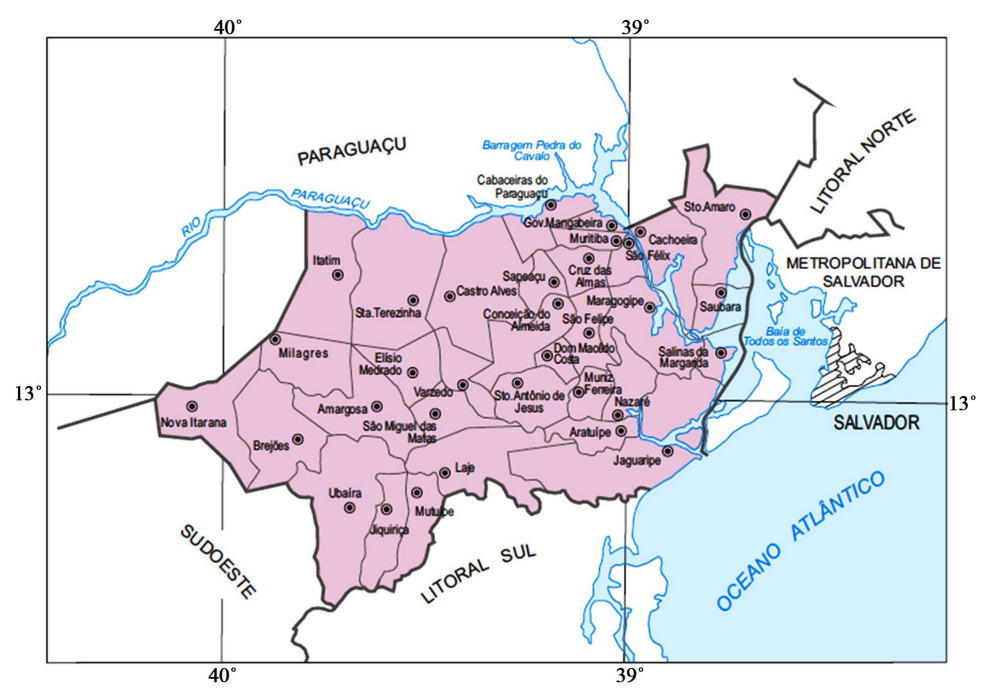

Figure 1. The Recôncavo region of Bahia, Brazil. 
Three collections were performed in each town, consisting of two samples of mullets (Mugil spp.), two samples of mussels (Mytella spp.), and two samples of mollusks (Anomalocardia brasiliana), with 54 samples total. Samples were kept in thermal boxes with ice and transported to the Laboratory of Microbiology and Animal Parasitology of the Universidade Federal do Recôncavo da Bahia.

\subsection{Microbiological Analysis}

Mesophyll heterotrophic bacteria were counted via depth plaques on Plate Count Agar (KASVI), and mold and yeast counts were performed via surface plaques on Agar Sabouraud Dextrose (KASVI). Total coliforms and Escherichia coli were counted via depth plaques on Chromocult ${ }^{\circledR}$ Coliform Agar (Merck). Staphylococcus aureus was counted using $3 \mathrm{M}^{\mathrm{Tm}}$ Petrifilm ${ }^{\mathrm{TM}}$ Staph Express. All the detections were done with the help of a colony contactor and using three repetions.

\subsection{Antimicrobial Sensitivity Test}

Strains were first recovered in Brain Heart Infusion (BHI) at $37^{\circ} \mathrm{C}$ for $24 \mathrm{~h}$. The inoculum was spread on medium Agar Mueller-Hinton (KASVI) with a sterile swab, and antimicrobial discs were added. Plates were incubated at $37^{\circ} \mathrm{C}$ for $24 \mathrm{~h}$ and inhibition haloes were measured using a millimeter ruler. Results were read according to parameters described by the Clinical and Laboratory Standards Institute [7]. Antimicrobials tested on Staphylococcus aureus were gentamicin (10 $\mu \mathrm{g})$, cefoxitin $(30 \mu \mathrm{g})$, ciprofloxacin $(5 \mu \mathrm{g})$, chloramphenicol (30 $\mu \mathrm{g})$, erythromycin $(15 \mu \mathrm{g})$, penicillin $(10 \mu \mathrm{g})$, oxacillin $(1 \mu \mathrm{g})$, clindamycin $(2 \mu \mathrm{g})$, vancomycin $(30 \mu \mathrm{g})$, and sulfametoxazol $(25 \mu \mathrm{g})$. Gentamicin $(10 \mu \mathrm{g})$, cefoxitin $(30 \mu \mathrm{g})$, ciprofloxacin $(5 \mu \mathrm{g})$, chloramphenicol $(30 \mu \mathrm{g})$, nitrofurantoin $(300 \mu \mathrm{g})$, tetracycline $(30 \mu \mathrm{g})$, ampicillin $(10 \mu \mathrm{g})$, amoxicillin $(30 \mu \mathrm{g})$, amikacin $(30 \mu \mathrm{g})$, and cephthazidim $(30 \mu \mathrm{g})$ were tested on Escherichia coli.

\subsection{DNA Extraction and PCR}

Escherichia coli isolates were kept in BHI broth with $20 \%$ glycerol and maintained at $-20^{\circ} \mathrm{C}$ for DNA extraction and Polymerase Chain Reaction (PCR). DNA was extracted by centrifuging $1 \mathrm{~mL}$ bacterial culture suspension in BHI broth at 13,200 rpm for $5 \mathrm{~min}$. The supernatant was discarded and $800 \mu \mathrm{L}$ of sterile milli-Q water was added. After homogenization, samples were centrifuged once more as previously described. The supernatant was discarded and $80 \mu \mathrm{L}$ of sterile milli-Q water was added. Samples were incubated in a warm bath at $96^{\circ} \mathrm{C}$ for 10 minutes. The supernatant was removed and maintained at $-20^{\circ} \mathrm{C}$ until analysis.

DNA underwent PCR to isolate the stx virulence gene. The following reagents and volumes were used: $3.0 \mu \mathrm{L}$ DNA; $2.5 \mu \mathrm{L}$ PCR buffer with $\mathrm{MgCl}_{2} ; 0.5 \mu \mathrm{L}$ dNTP; $1.0 \mu \mathrm{L}$ each of primer 1 and 2 ; and $0.1 \mu \mathrm{L}$ Taq DNA polymerase. The final volume was adjusted to $25 \mu \mathrm{L}$ with sterile milli- $\mathrm{Q}$ water. 
The positive control consisted of a standard strain of enterohemorrhagic $E$. coli (EHEC) (ATCC 43895), provided by the Oswaldo Cruz Foundation (Fiocruz) in Rio de Janeiro, Brazil. Amplification reactions were performed in an Amplitherm ${ }^{\oplus}$ TX96 Plus thermocycler. Table 1 shows PCR conditions, primer sequences, and amplified fragment size.

Amplified PCR products underwent 2\% agar gel electrophoresis using a horizontal electrophoresis system with a $50 \mathrm{bp}$ size and molecular weight marker. Electrophoresis was run using a digital source GSR ${ }^{\circledR}$ 200STD. Loading Dye 6X Promega ${ }^{\circledR}$ and SYBR Green Life Technologies ${ }^{\circledR}$ were used to visualize PCR products in ultraviolet Loccus L-PIX photodocumentation.

\subsection{Statistical Analysis}

$\mathrm{CFU} / \mathrm{g}$ rates were transformed by log CFU/g, and means underwent analysis of variance by Tukey's at $\mathrm{p} \leq 0.05$. Analyses were performed with the statistical program R 3.4.1 [8].

\section{Results}

\subsection{Microbiological Analysis}

Mean mesophyll, mold, and yeast counts in mullet samples were not significantly different in different towns, and there were no differences among microorganisms (Table 2). Total coliform counts ranged between 0 and $9.5 \mathrm{CFU} / \mathrm{g}$.

E. coli was detected in $20.4 \%$ (11/54) of mussel samples in the three towns (Table 3). In the case of Staphylococcus aureus, 16.7\% (9/54) of samples had a contamination rate higher than $10^{3} \mathrm{CFU} / \mathrm{g}(3 \log \mathrm{CFU} / \mathrm{g})$, the upper safety limit established by RDC n.12. Mussels had the highest count rate, ranging between 0 and $3.95 \log \mathrm{CFU} / \mathrm{g}$. The town of Cruz das Almas had the greatest average rate for this pathogen.

Table 1. Primer sequences, amplified fragment size, and PCR conditions used for gene detection associated with virulence.

\begin{tabular}{|c|c|c|c|}
\hline Gene/pathotype & primer 5'-3' sequence & $\begin{array}{l}\text { Fragment } \\
\text { size }(\mathrm{pb})\end{array}$ & PCR conditions \\
\hline stx/EHEC & TTT ACG ATA GAC TTC TCG AC CAC ATA TAA ATT ATT TCG CTC & 227 & $\begin{array}{c}5 \min 94^{\circ} \mathrm{C} / 35 \text { cycles of } \\
1 \min 94^{\circ} \mathrm{C} ; 3 \min 48^{\circ} \mathrm{C} \text { and } \\
4 \min 72^{\circ} \mathrm{C} / 10 \min 72^{\circ} \mathrm{C}\end{array}$ \\
\hline
\end{tabular}

Table 2. Mean rates of microbiota (in $\log \mathrm{CFU} / \mathrm{g}$ ) in mullet samples (Mugil sp.) from three towns in the Recôncavo da Bahia region, Brazil.

\begin{tabular}{cccc}
\hline & Cachoeira & Cruz das Almas & Santo Antônio de Jesus \\
\hline Total coliforms & $3.17 \mathrm{aA}$ & $5.68 \mathrm{bB}$ & $4.32 \mathrm{bB}$ \\
Escherichia coli & $2.53 \mathrm{bA}$ & $3.01 \mathrm{bA}$ & $1.05 \mathrm{aA}$ \\
Mesophylls & $6.46 \mathrm{aB}$ & $7.94 \mathrm{aB}$ & $6.08 \mathrm{aB}$ \\
Molds and yeast & $6.78 \mathrm{aB}$ & $6.28 \mathrm{aB}$ & $5.88 \mathrm{aB}$ \\
Staphylococcus aureus & $2.68 \mathrm{aA}$ & $2.69 \mathrm{aA}$ & $1.49 \mathrm{aA}$ \\
\hline
\end{tabular}

Rates with the same lowercase letter in each row and the same uppercase letter in each column do not differ statistically by Tukey's test with $5 \%$ probability. 
Table 3. Mean rates of microbiota (in log CFU/g) in mussel samples (Mytella sp.) from three towns in the Recôncavo from Bahia region, Brazil.

\begin{tabular}{cccc}
\hline & Cachoeira & Cruz das Almas & Santo Antônio de Jesus \\
\hline Total coliforms & $4.92 \mathrm{aB}$ & $6.43 \mathrm{bB}$ & $6.43 \mathrm{bB}$ \\
Escherichia coli & $1.79 \mathrm{aA}$ & $4.00 \mathrm{bA}$ & $2.68 \mathrm{aA}$ \\
Mesophylls & $6.28 \mathrm{aC}$ & $7.09 \mathrm{bC}$ & $7.99 \mathrm{bC}$ \\
Molds and yeasts & $6.45 \mathrm{aC}$ & $7.91 \mathrm{bC}$ & $6.84 \mathrm{aB}$ \\
Staphylococcus aureus & $1.13 \mathrm{aA}$ & $3.91 \mathrm{bA}$ & $1.22 \mathrm{aA}$ \\
\hline
\end{tabular}

Rates with the same lowercase letter in each row and the same uppercase letter in each column do not differ statistically by Tukey's test with $5 \%$ probability.

The mean rate of Escherichia coli occurrence was detected in mollusks, and no statistical difference was detected between Cruz das Almas and Santo Antônio de Jesus (Table 4).

\subsection{Antimicrobial Sensitivity}

Results of the antimicrobial sensitivity test reveal that $85.4 \%, 72.9 \%$, and $54.2 \%$ of the 48 isolates were resistant to Staphylococcus aureus, penicillin and oxacillin, and sulfametoxazol, respectively (Table 5).

All 69 Escherichia coli strains tested were resistant to at least one of the ten antimicrobial agents (Table 6).

\subsection{Virulence Gene Research}

For Escherichia coli O157: H7, 55.6\% (30/50) of the samples were presumably positive on fluorocult Escherichia coli O157:H7 Agar. However, no stx gene was identified in any of the samples studied (Figures 2-4).

\section{Discussion}

An upper limit of $5 \times 10 \mathrm{CFU} / \mathrm{g}$ or $1.70 \mathrm{log} \mathrm{CFU} / \mathrm{g}$ of thermotolerant coliforms has been established for cooked, industrialized, cooled, or frozen bivalve mollusks [9]. In this study, Escherichia coli was detected in 31.5\% of mollusk samples, indicating a breach of this limit. In fact, E. coli was the main agent detected from this group of investigated contaminants, indicating fecal contamination.

Current legislation does not establish parameters for the analysis of mesophyll heterotrophic bacteria, even though counts are very important for estimating microbial load. In fact, most food borne pathogenic microorganisms are mesophyll agents. Furthermore, high mesophyll counts may indicate problems in handling and storage.

Evangelista-Barreto et al. [10] evaluated the hygiene and sanitary conditions of fish sold in the town of Cruz das Almas, Bahia, Brazil and detected mesophyll counts ranging between 6.67 and $6.83 \mathrm{log} \mathrm{CFU} / \mathrm{g}$ in fresh fish. Sousa et al. [11] reported a maximum count of $7.96 \mathrm{log} \mathrm{CFU} / \mathrm{g}$ in tilapia samples from sport fishing in Salinas, MG, Brazil. 

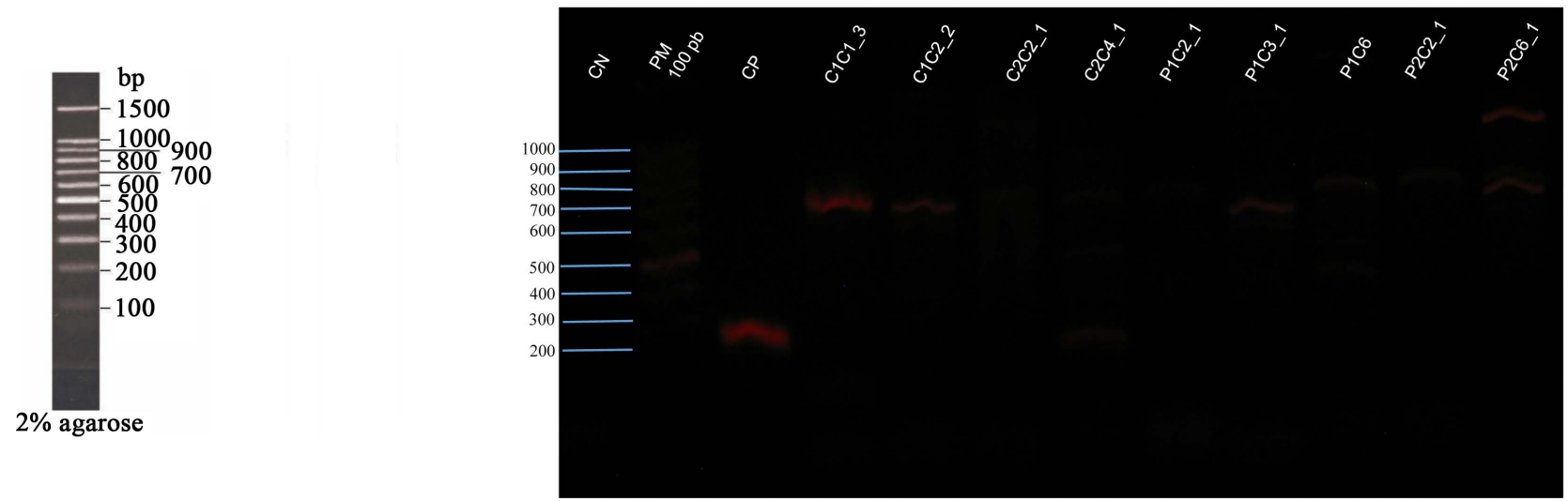

Figure 2. PCR and run performed on 11/28/2018/Gene stx_EHEC/2\% Agarose Gel/run 80 V/65 mA/2 hours.
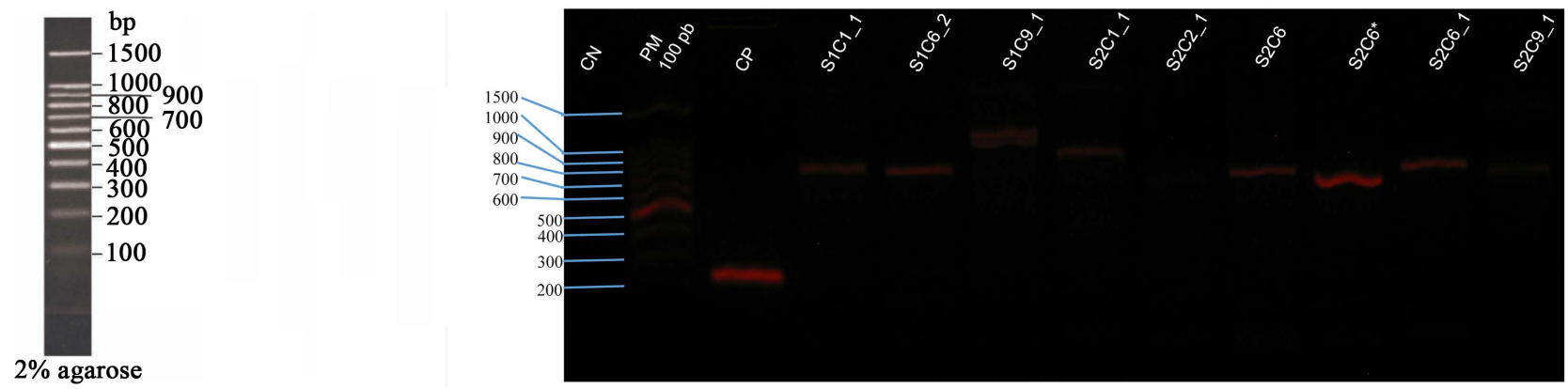

Figure 3. PCR performed on 11/29/2018/Gene stx_EHEC/Race performed on 11/30/2018-2\% Agarose Gel/80 V run/65 mA/1 h and 20 min-FOTO_GEL 1.
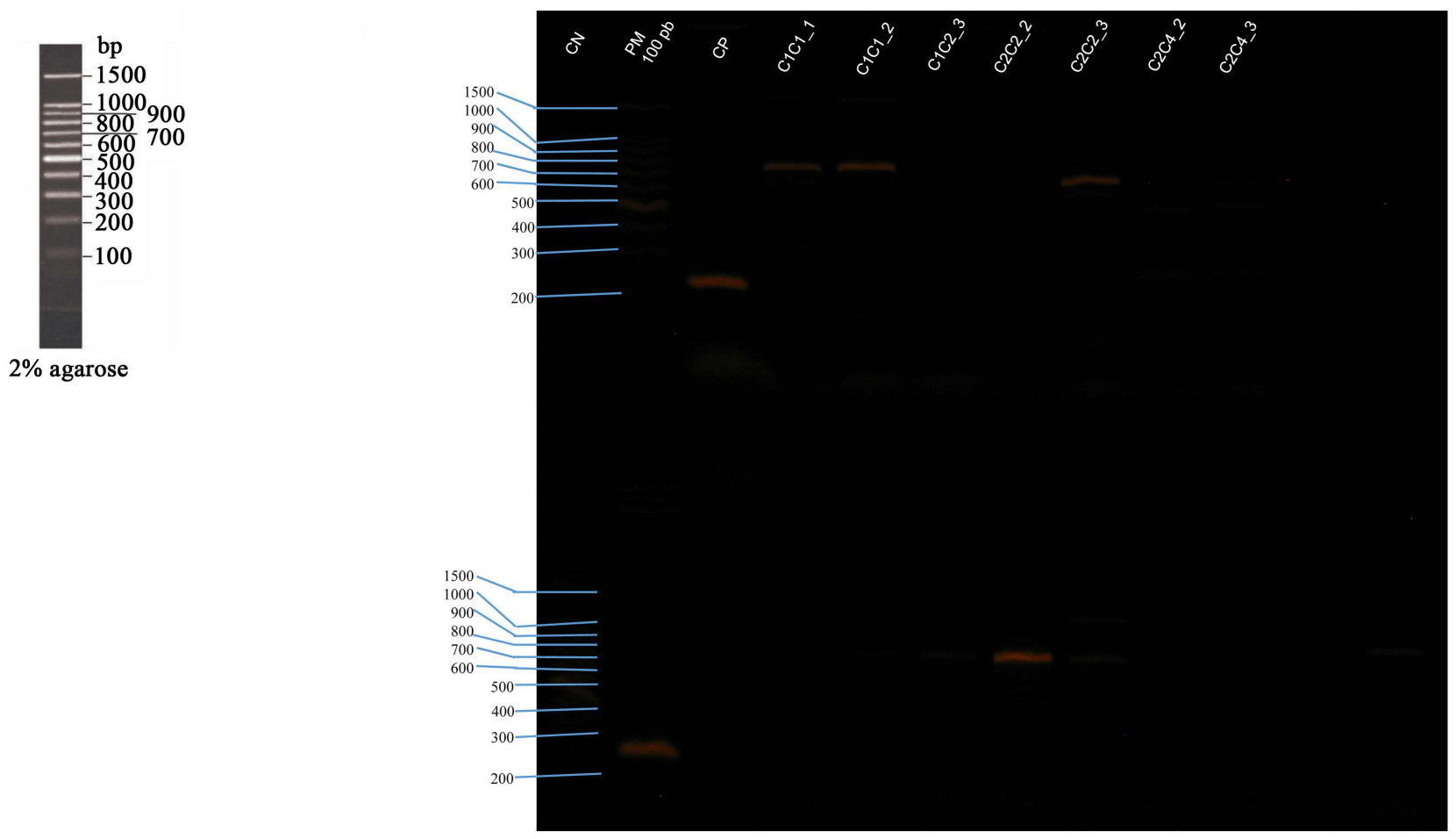

Figure 4. PCR performed on 12/04/2018/Gene stx_EHEC/Race performed on 12/05/2018-2\% Agarose Gel/80 V run/65 mA/1 h and $20 \mathrm{~min}$. 
Table 4. Mean rates of microbiota (inlog CFU/g) in mollusk samples (Anomalocardia brasiliana) from three towns in the Recôncavo from Bahia region, Brazil.

\begin{tabular}{cccc}
\hline & Cachoeira & Cruz das Almas & Santo Antônio de Jesus \\
\hline Total coliforms & $4.83 \mathrm{bB}$ & $3.79 \mathrm{aB}$ & $3.37 \mathrm{aB}$ \\
Escherichia coli & $0.72 \mathrm{aA}$ & $2.36 \mathrm{bA}$ & $1.71 \mathrm{aA}$ \\
Mesophylls & $4.67 \mathrm{aB}$ & $6.14 \mathrm{bC}$ & $6.85 \mathrm{bC}$ \\
Molds and yeasts & $4.67 \mathrm{aB}$ & $6.18 \mathrm{bC}$ & $6.76 \mathrm{bC}$ \\
Staphylococcus aureus & $1.48 \mathrm{aA}$ & $2.92 \mathrm{bA}$ & $1.49 \mathrm{aA}$ \\
\hline
\end{tabular}

Rates with the same lowercase letter in each row and the same uppercase letter in each column do not differ statistically by Tukey's test with $5 \%$ probability.

Table 5. Antimicrobial sensitivity of Staphylococcus aureus isolates in fish, mussel, and mollusk samples from three towns in the Recôncavo from Bahia, Brazil.

\begin{tabular}{|c|c|c|c|c|c|c|c|c|c|}
\hline \multirow{2}{*}{ Antimicrobial agents } & \multicolumn{3}{|c|}{ Fish (16) } & \multicolumn{3}{|c|}{ Mussel (14) } & \multicolumn{3}{|c|}{ Mollusk (18) } \\
\hline & $\mathrm{R}$ & I & S & $\mathrm{R}$ & I & S & $\mathrm{R}$ & I & S \\
\hline \multicolumn{10}{|l|}{$\beta$-lactam antibiotics } \\
\hline Penicillin & 81.3 & 0 & 18.7 & 87.5 & 0 & 12.5 & 88.9 & 0 & 11.1 \\
\hline Oxacillin & 68.8 & 6.2 & 25 & 100 & 0 & 0 & 55.6 & 0 & 44.4 \\
\hline Cefoxitin & 18.7 & 12.5 & 68.8 & 50 & 14.3 & 35.7 & 22.2 & 5.6 & 72.2 \\
\hline \multicolumn{10}{|l|}{ Glycopeptides } \\
\hline Vancomycin & 31.2 & 0 & 68.8 & 50 & 0 & 50 & 22.2 & 0 & 77.8 \\
\hline \multicolumn{10}{|l|}{ Aminoglycosides } \\
\hline Gentamicin & 0 & 0 & 100 & 7.1 & 0 & 92.9 & 0 & 11.1 & 88.9 \\
\hline \multicolumn{10}{|l|}{ Phenicols } \\
\hline Chloramphenicol & 0 & 12.5 & 87.5 & 7.1 & 0 & 92.9 & 16.7 & 11.1 & 72.2 \\
\hline \multicolumn{10}{|l|}{ Quinolone } \\
\hline Ciprofloxacin & 6.2 & 18.7 & 75 & 7.1 & 0 & 92.9 & 0 & 27.8 & 72.2 \\
\hline \multicolumn{10}{|l|}{ Lincosamides } \\
\hline Clindamycin & 68.8 & 6.2 & 25 & 100 & 0 & 0 & 22.2 & 66.7 & 11.1 \\
\hline \multicolumn{10}{|l|}{ Macrolides } \\
\hline Erythromycin & 31.2 & 31.2 & 37.5 & 28.6 & 57.1 & 14.3 & 22.2 & 50 & 27.8 \\
\hline \multicolumn{10}{|l|}{ Sulfonamides } \\
\hline Sulfametoxazol & 50 & 0 & 50 & 71.4 & 0 & 28.6 & 44.4 & 0 & 55.6 \\
\hline
\end{tabular}

R-resistant; I-intermediate; $\mathrm{S}$-sensitive. Numbers indicate percentages.

According to the Sanitation Protection Agency, fungi may cause deterioration at slightly lower levels $(6-7 \log \mathrm{CFU} / \mathrm{g})$ than gram-negative bacteria due to the production of gas and acid, [12]. In fact, $39.26 \%$ (32/54) of the fish in this study were undergoing a fungal deterioration process that would, in turn, trigger allergic reactions. Consequently, high microbial load may indicate subpar hygiene conditions for utensils, failure in processing and/or storage conditions, or excessive contamination of the primary matter. 
Table 6. Antimicrobial resistance of Escherichia coli isolates in fish, mussels, and mollusk samples from three towns in the Recôncavo from Bahia region, Brazil.

\begin{tabular}{|c|c|c|c|c|c|c|c|c|c|}
\hline \multirow{2}{*}{ Antimicrobial agents } & \multicolumn{3}{|c|}{ Fish (27) } & \multicolumn{3}{|c|}{ Mussel (30) } & \multicolumn{3}{|c|}{ Mollusk (12) } \\
\hline & $\mathrm{R}$ & I & S & $\mathrm{R}$ & I & $S$ & $\mathrm{R}$ & I & $S$ \\
\hline \multicolumn{10}{|l|}{$\beta$-lactam antibiotics } \\
\hline Cefoxitin & 77.8 & 7.4 & 14.8 & 66.7 & 6.7 & 26.7 & 91.7 & 8.3 & 0 \\
\hline Ampicillin & 81.5 & 7.4 & 11.1 & 70 & 10 & 20 & 75 & 8.3 & 16.7 \\
\hline Amoxicillin & 81.5 & 11.1 & 7.4 & 73.3 & 6.7 & 20 & 75 & 25 & 0 \\
\hline Cephthazidim & 7.4 & 14.8 & 77.8 & 6.7 & 6.7 & 86.6 & 8.3 & 0 & 91.7 \\
\hline \multicolumn{10}{|l|}{ Tetracyclins } \\
\hline Tetracycline & 48.2 & 11.1 & 40.7 & 23.3 & 10 & 66.7 & 50 & 8.3 & 41.7 \\
\hline \multicolumn{10}{|l|}{ Aminoglycosides } \\
\hline Gentamycin & 0 & 0 & 100 & 0 & 0 & 100 & 0 & 0 & 100 \\
\hline Amikacin & 3.7 & 11.1 & 85.2 & 0 & 0 & 100 & 8.3 & 16.7 & 75 \\
\hline \multicolumn{10}{|l|}{ Phenicols } \\
\hline Chloramphenicol & 11.1 & 14.8 & 74.1 & 13.3 & 0 & 86.7 & 0 & 25 & 75 \\
\hline \multicolumn{10}{|l|}{ Quinolones } \\
\hline Ciprofloxacin & 0 & 0 & 100 & 3.3 & 6.7 & 90 & 0 & 0 & 100 \\
\hline \multicolumn{10}{|l|}{ Nitrofurantoins } \\
\hline Nitrofurantoin & 59.3 & 11.1 & 29.6 & 50 & 6.7 & 43.3 & 41.7 & 25 & 33.3 \\
\hline
\end{tabular}

R-resistant; I-intermediary; S-sensitive. Numbers indicate percentages.

Pinheiro et al. [13] reported contamination with filamentous fungi in 63\% of fish retrieved from fish farms in the municipality of São Luís-MA. Furthermore, Alves et al. [14] detected $60 \mathrm{CFU} / \mathrm{g}$ of molds and yeasts when they analyzed samples of Nile tilapia in naturain the state of Paraná, Brazil.

RDC n. 12 of the Brazil Agency for Sanitation Vigilance [9] fails to establish limits for total coliforms in food, even though coliforms may indicate unsatisfactory hygiene conditions and food contamination.

Total coliforms in food do not necessarily indicate fecal contamination or the occurrence of enteropathogens, but do indicate hygienic faults throughout the preparation process or even post-industrialization contamination [15].

The presence of Escherichia coli in in natura food demonstrates recent fecal contamination and the possible presence of other enteric pathogens, such as Klebsiella, or poor hygienic conditions. Pathogenic strains may cause diarrhea, hemorrhagic colitis, meningitis, uremic syndrome, and septicemia [16]. Similar results were obtained by Farias et al. [17], who analyzed mussel samples at the mouth of the river Vaza Barris in Sergipe, Brazil, and detected pathogenic strains of E. coli. Mafra et al. [18] corroborated this finding when they analyzed mollusk samples commercialized in the municipal market of Maragogipe BA Brazil; they 
detected $E$. coli in $66.7 \%$ of the samples.

E. coli is a non-indigenous microorganism in fish and is not part of its normal biota. In other words, the isolation of this microorganism in food may be associated with fecal contamination when the fish were caught, cross-contamination during transport and handling, or contamination of utensils used or of the ice that comes in contact with fresh fish. All of these occurrences reflect poor hygiene and sanitary conditions [19] [20].

Freitas et al. [21] analyzed mussels industrialized by the Maroon community in the Baía do Iguape and reported that $33.33 \%$ of unshelled samples were contaminated with $S$. aureus. In fact, unwashed mussels had the highest contamination rates. According to the authors, contamination occurred because of human handlers who were asymptomatic bearers of $S$. aureus, and by recontamination from contact with badly washed utensils, putting consumers at risk for food intoxication.

Lack of information on Good Handling Practices contributes to worsening mollusk contamination, especially with regard to time-temperature and crossedcontamination involving utensils. Furthermore, bivalve mollusks feed by filtration, which leads to greater microbial density in mollusks compared to fish. They accumulate several microorganisms in their tissues when they are extracted from areas polluted by domestic sewage. There is an almost guaranteed lack of hygiene and sanitation conditions when the valve removal process is undertaken at workers' homes [22].

Staphylococcus aureus showed the greatest resistance to penicillin and oxacillin, which belong to the $\beta$-lactam antibiotics class. There are several bacterial protection strategies against $\beta$-lactam antibiotics, including the destruction of this drug group through the production of beta-lactamase, decreasing the antibiotics' penetrative ability, and reducing affinity for PBP (penicillin binding proteins) [23].

Resistant bacterial strains vectored in food are of great concern, particular those resistant to antimicrobial agents in the $\beta$-lactam antibiotics group, which are highly employed in the control of infectious diseases [24]. The sensitivity of Staphylococcus aureus isolates to ciprofloxacin, which belongs to the quinolones class, has been reported. There are also drugs in veterinary medicine used to treat bacterial infections in fish [25].

Costa et al. [26] analyzed the resistance profile of $S$. aureus isolates in acoupa fish (Cynoscion acoupa) sold in the town fair in Macapá, Brazil. They were resistant to penicillin (100\%), vancomycin (86.7\%), clindamycin $(66.7 \%)$, and erythromycin (33.3\%). According to the authors, resistance may be due to the contamination of the $C$. acoupa's natural habitat with drugs or antimicrobial compounds, or the contamination of fish by handlers with $S$. aureus resistant to the tested antimicrobial agents. Resistance may have been caused by horizontal gene transfer between bacterial populations within the natural environment.

All Escherichia coli isolates were sensitive to gentamicin, which belongs to the aminoglycoside class, employed either alone or combined with beta-lactam anti- 
biotics for the treatment of infections in fish farming, even though the nephrotoxicity of these antimicrobial agents for fish has not been fully examined [27]. However, a study conducted by Dias et al. [28] led to different results. When the authors analyzed antimicrobial resistance in $E$. coli strains isolated from mussels in the municipality of Niteroi, Brazil, they found that less than $20 \%$ of isolates were sensitive to gentamicin.

Laroche et al. [29] reported that E. coli strains isolated from anaqueous environment had greater antimicrobial resistance to chloramphenicol and tetracycline.

Escherichia coli is a common bacterium that lives in the intestinal tract of homeothermal animals. It is an important microorganism for the study of the prevalence of intestinal bacteria resistant to antimicrobial agents. Products of animal origin have high occurrences of $E$. coli from fecal contamination. Microorganisms and their antimicrobial resistance genes may be transmitted to humans if food is not properly cooked [10].

Antimicrobial resistance against five antimicrobial agents from the $\beta$-lactam family of antibiotics, primarily ampicillin and amoxicillin, may be due to the worldwide employment of these antimicrobial agents to control infectious diseases [30].

Increases in resistant bacteria in environmental areas have been attributed to water contamination, the launching of antimicrobial wastes from domestic effluents, and the presence of animal farming. These conditions have led to the installation, maintenance, and propagation of resistance among bacterial populations within the aquatic environment [31].

There are two classes of Shiga toxins, namely Stx 1 and Stx2. This study focuses on the gene stx1, although stx2-producing strains are more connected to hemoragric uremic syndrome ( $\mathrm{SHU}$ ) than stx1-producing strains [32]. The absence of the gene stx1 does not exclude the possibility of detecting stx2.

Cardozo et al. [33] analyzed fish intended for human consumption and detected the genes $s t x 1, s t x 2$, and eae in $6.06 \%$ (6/99) of fish feces samples. No muscle or water samples were positive for the Shiga toxin producing Escherichiacoli (STEC) or Enteropathogenic Escherichiacoli (EPEC) markers investigated.

\section{Conclusion}

The quality of fish sold in town fairs in the towns of Cachoeira, Cruz das Almas, and Santo Antônio de Jesus was found to be subpar due to high microbial load and a pronounced deterioration stage. This jeopardizes the safety of the food and puts consumers' health at risk due to the contamination indexes of fecal origin and of Staphylococcus aureus, which is pathogenic for humans. Furthermore, the resistance of $S$. aureus and $E$. coli to several antimicrobial agents demonstrates that the environment they were retrieved from was subjected to antimicrobial agents or resistant microorganisms, affecting resident microbiota. 


\section{Acknowledgements}

The authors would like to thank FAPESB for the scholarship granted. Thanks are also due to CEFAR for donation of antimicrobial discs.

\section{Conflicts of Interest}

The authors declare no conflicts of interest regarding the publication of this paper.

\section{References}

[1] Gonçalves, A.L.M.M., Dias, I.C.L., Nascimento, D.L. and Silva, M.I.S. (2012) Hygienic-Sanitary Profile of Consumers and Establishments Commercializing Fish from the City of Paço do Lumiar e São José de Ribamar, MA. Tecnological Acta, 7, 25-30.

[2] Soares, K.M.P. and Gonçalves, A.A. (2012) Quality and Safety of Fish. Adolfo Lutz Institute Journal, São Paulo, 71, 1-10.

[3] Silva, A.T.F., Rocha, P.G.G., Fonseca Filho, L.B., Costa, C.A., Nascimento, J.C.S. and Carvalho Neto, P.M. (2017) Microbial Alterations of Cured Fish Products: Review. Pubvet, 11, 658-661. https://doi.org/10.22256/pubvet.v11n7.658-661

[4] Nunes, E.S.C.L., Franco, R.M., Mársico, E.T., Nogueira, E.B., Neves, M.S. and Silva, F.E. (2012) Indigenous Bacteria and Pathogens in Salted and Dried Pirarucu (Arapaima gigas Shing, 1822) Traded in Belém, Pará. Brazilian Journal of Veterinary Research Animal Science, 19, 98-103. https://doi.org/10.4322/rbcv.2014.084

[5] Nespolo, N.M., Saba, R.Z., Rossatelli, D.A., Fairbrother, J.M. and Rossi Júnior, O.D. (2014) Occurrence of Escherichia coli O157:H7 e O26 Sorbitol Negative in a Cattle Slaughterhouse and Susceptibility to Antimicrobials. Biological Institute Files, 81, 209-217. https://doi.org/10.1590/1808-1657001332012

[6] Slama, K.B., Jouini, A., Sallen, R.B., Somalo, S., Sáenz, Y., Estepa, V., Boudabous, A. and Torres, C. (2010) Prevalence of Broad-Spectrum Cephalosporin-Resistant Escherichia coli Isolates in Food Samples in Tunisia, and Characterization of Integrons and Antimicrobial Resistance Mechanisms Implicate. International Journal Food Microbiology, 137, 281-286. https://doi.org/10.1016/j.ijfoodmicro.2009.12.003

[7] CLSI. Clinical and Laboratory Standards Institute (2010) Performance Standards for Antimicrobial Susceptibility Testing, Twenty-Four Informational Supplement. CLSI Document M49-A. Clinical and Laboratory Standards Institute, Wayne.

[8] R Core Team (2017) R: A Language and Environment for Statistical Computing. R Foundation for Statistical Computing, Vienna.

[9] Brazil. Resolution $\mathrm{n}^{\circ} 12$ of January 2 of 2001. Technical Regulation on Microbiological Standards for Food. Federal Official Gazette of Brazil, Executive Branch, Brasília.

[10] Evangelista-Barreto, N.S., Moura, F.C.M., Teixeira, J.A., Assim, D.A. and Miranda, P.C. (2012) Evaluation of the Hygienic-Sanitary Conditions of Fish Commercialized in Cruz das Almas, Bahia. Caatinga Journal, 25, 86-95.

[11] Sousa, F.A., Rodrigues, R.A., Arruda, F.A., Santos, W.L.M. and Santos, T.M. (2017) Hygienic-Sanitary and Technological Characterization of Fishermen and Nile Tilapia (Oreochromis niloticus) Sold in Salinas-MG Municipal Market. Brazilian Journal of Veterinary Sciences, 24, 197-200. https://doi.org/10.4322/rbcv.2017.037

[12] HPA Health Protection Agency (2009) Guidelines for Assessing the Microbiological Safety of Ready-to-Eat Foods. Health Protection Agency, London. 
[13] Pinheiro, C.A.M., Pinheiro, R.S., Santos, W.H.L., Serra, I.M.R.S. and Santos, D.M.S. (2015) Water Quality and the Incidence of Fungi in Farmed Fish from São LuísMaranhão. Research on Focus, 20, 53-69.

[14] Alves, G., Zabine, L., Bantle, J.F., Rodrigues, L.C.S., Pasquali, R. and Nascimento, I.A. (2010) Physicochemical, Microbiological and Sensorial Evaluation of Clean Whole Nile Tilapias (Oreochromis niloticus) Submitted to Salting and Natural Drying. Journal of Veterinary Sciences \& Zoology Files from Unipar, 13, 71-75.

[15] Chouman, K., Ponsano, E.H.G. and Michelin, A.P. (2010) Microbiological Quality of Food from Self-Service Restaurants. Adolfo Lutz Institute Journal, 69, 261-266.

[16] Jafari, A., Aslani, M.M. and Bouzari, S. (2012) Escherichia coli: A Brief Review of Diarrheagenic Pathotypes and Their Role in Diarrheal Diseases in Iran. Iranian Journal of Microbiology, 4, 102-117.

[17] Farias, K.L., Trindade, R.C. and Alcântara, A.V. (2010) Occurrence of E. coli (EPEC e EIEC) in Mussel, Mytella guayanensis Lamarck, and in the Water of Vaza-Barris River Estuary, Sergipe State, Brazil. Marine Science Files, 43, 66-70.

[18] Mafra, J.F., Marques, V.F., Carneiro, C.S., Oliveira, T.A.S. and Evangelista-Barreto, N.S. (2016) Microbiological Quality Evaluation of Bivalve Mollusks Processed and Commercialized in Maragogipe, Bahia State, Brazil. Acta of Fisheries and Aquatic Resources, 4, 39-43.

[19] Santiago, J.A.S., Araújo, P.F.R., Santiago, A.P., Carvalho, F.C.T. and Vieira, R.H.S.F. (2013) Pathogenic Bacteria Related to Ingestion of Fish-A Review. Marine Science Files, 46, 92-103.

[20] Ferreira, E.M., Lopes, I.S., Pereira, D.M., Rodrigues, L.C. and Costa, F.N. (2014) Microbiological Quality of the Fish Saw (Scomberomorus brasiliensis) and the Ice Used for Its Conservation. Arquivos do Instituto Biológico, 81, 49-54. https://doi.org/10.1590/S1808-16572014000100009

[21] Freitas, F., Neiva, G.S., Cruz, E.S., Santana, J.S., Silva, I.M.M. and Mendonça, F.S. (2017) Microbiological Quality and Environmental Factors of Estuarine Area of Iguape Bay Marine Reserve (Bahia) for Cultivation of Native Oysters. Sanitary Engineering Journal, 22. https://doi.org/10.1590/s1413-41522016153707

[22] Evangelista-Barreto, N.S., Damacena, S.S., Cardoso, L.G., Marques, V.F. and Silva, I.P. (2017) Hygienic-Sanitary Conditions and Degree of Freshness of Fish Products Sold in the Fish Market in Cachoeira, Bahia. Brazilian Journal Hygiene and Animal Sanity, 11, 60-74. https://doi.org/10.5935/1981-2965.20170007

[23] Zhanel, G.G., Hisanaga, T.L., Laing, N.M., DeCorby, M.R., Nichol, K.A., Palatnik, L.P., Johnson, J., Noreddin, A., Harding, G.K., Nicolle, L.E. and Hoban, D.J. (2005) Antibiotic Resistance in Escherichia coli out Patient Urinary Isolates: Final Results from the North American Urinary Tract Infection Collaborative Alliance (NAUTICA). International Journal of Antimicrobial Agents, 26, 380-388. https://doi.org/10.1016/j.ijantimicag.2005.08.003

[24] Manjusha, S. and Sarita, G.B. (2013) Characterization of Plasmids from Multiple Antibiotic Resistant Vibrios Isolated from Molluscan and Crustacean of Kerala. International Food Research Journal, 20, 77-86.

[25] Costa, M.M., Peixoto, R.M., Boijink, C.L., Castagna, L., Meurer, F. and Vargas, A.C. (2008) Antimicrobial Sensitivity of Bacteria Isolates from Jundiá (Rhandia quelen). Brazilian Journal of Veterinary Research, 28, 477-480. https://doi.org/10.1590/S0100-736X2008001000006

[26] Costa, A.L.P., Nascimento, J.F. and Silva Júnior, A.C.S. (2018) Resistance Profile of Staphylococcus aureus Strains Isolated from Acoupa Weakfish (Cynoscion acoupa) 
Commercialized in Public Fair. Pubvet, 12, 1-6.

https://doi.org/10.22256/pubvet.v12n5a84.1-6

[27] Amarante, J.F., Kolling, L., Ferronato, A.I., Vargas, A.C., Costam, M.M. and Amarante, T.A.B. (2018) Antimicrobial Drugs Resistance of Bacteria from Carp (Cyprinus carpio) Raised in a Semi-Intensive System. Brazilian Animal Science Journal, 19, 1-7. https://doi.org/10.1590/1809-6891v19e-34647

[28] Dias, M.T., Santos, P.C.R.F., Oliveira, L.A.T. and Marin, V.A. (2010) Evaluation of Antimicrobial Sensibility of Escherichia coli Strains Isolated from Mussel (Perna perna Linnaeus 1758). Food Science and Technology, 30, 319-324. https://doi.org/10.1590/S0101-20612010000200005

[29] Laroche, E., Petit, F., Fournier, M. and Pawlak, B. (2010) Transport of Antibiotic-Resistant Escherichia coli in a Public Rural Karst Water Supply. Journal of $\mathrm{Hy}$ drology, 392, 12-21. https://doi.org/10.1016/j.jhydrol.2010.07.022

[30] Ahmed, N., Kamal, M., Kamran, A. and Zaidi, A.H. (2016) Frequency of Extended Spectrum Beta-Lactamases in Enterobacteriaceae in Urinary Isolates Related to Age and Gender. Medical Channel Journal, 22, 16-20.

[31] Vivant, A.L., Boutin, C., Prost-Boucle, S., Papias, S., Hartmann, A., Depret, G., Ziebal, C., Le Roux, S. and Pourcher, A.M. (2016) Free Water Surface Constructed Wetlands Limit the Dissemination of Extended-Spectrum Beta-Lactamase Producing Escherichia coli in the Natural Environment. Water Research, 104, 178-188. https://doi.org/10.1016/j.watres.2016.08.015

[32] Paton, A.W. and Paton, J.C. (1998) Detection and Characterization of Shiga Toxigenic Escherichia coli by Using Multiplex PCR Assays for stx1, stx2, eaeA, Enterohemorrhagic E. coli hlyA, rfbO111, and rbfO157. Journal of Clinical Microbiology, 36, 598-602.

[33] Cardozo, M.V., Borges, C.A., Beraldo, L.G., Maluta, R.P., Pollo, A.S., Borzi, M.M., Santos, L.F., Kariyawasam, S. and Ávila, F.A. (2018) Shigatoxigenic and Atypical Enteropathogenic Escherichia coli in Fish for Human Consumption. Brazilian Journal of Microbiology, 49, 936-941. https://doi.org/10.1016/j.bjm.2018.02.013 